\title{
A Research on the General and Financial Problems of Agricultural Sector in North Cyprus: Case of Karpaz Peninsula
}

\author{
Assoc.Prof.Dr. Okan Veli ŞAFAKLI \\ European University of Lefke, Faculty of Business and Economics, Lefke-Northern Cyprus \\ Email: osafakli@eul.edu.tr \\ Dr. Mustafa ERTANIN \\ European University of Lefke, Faculty of Business and Economics, Lefke-Northern Cyprus \\ Email: mertanin@eul.edu.tr; ertanin@hotmail.com
}

\section{Dr. Hüda HÜDAVERDi}

Girne American University, Faculty of Business and Economics, Girne-Northern Cyprus Email: hhudaverdi@gau.edu.tr

DOI: 10.6007/IJARBSS/v3-i7/19 URL: http://dx.doi.org/10.6007/IJARBSS/v3-i7/19

\begin{abstract}
The following research focuses on agricultural and farming enterprises located in Iskele Province of Karpaz Peninsula in Turkish Republic of North Cyprus (TRNC), accenting on and examining overall and financial issues and problems.In this frame, the main problems of agriculture in order, are: 'Position of Karpaz in regard to land use, in Cyprus Conflict', 'Natural disasters', 'Bureaucratic obstacles', 'Negative effects of Cyprus Issue', 'Marketing of products,', 'Competing with South Cyprus and imported foreign products' and ,'Finance'.Entrepreneurs and businesses in agriculture state that, the most important dimensions of financial problem are 'High finance cost', 'Difficulties encountered in collections from market and official bodies', 'Limited incentive opportunity', 'Collateral and debenture obligations demanded for loans', 'Costly capital investment funds "Insufficient local business capital and problems encountered procuring the business capital' and 'Insufficient equity and difficulties faced in obtaining investment credit.'
\end{abstract}

Keywords: TRNC, Agricultural Production, General and Financial Problems, Case of Karpaz Region

\section{INTRODUCTION}

In TRNC, compared with economic development, a decline in the importance of agriculture is observed. However, its' strategic position being in the first place, it has a significant role in employment and export revenues. Current and ongoing project of supplying water to TRNC 
with undersea pipeline from Turkey naturally will increase the significance of irrigated agriculture in the north part of island.

Increasing the productivity and efficiency in agricultural sector is only possible with the detailed assessment of existing problems and the preparation of remedy and development plans. This is why Karpaz Area, where agriculture is highly practiced is designated as research environment. Context of the research and study aims at determining the general and financial problems of agriculture sector in TRNC.

Main body of the study consists of current structure and importance of Turkish Cypriot agriculture sector, methodology, findings and discussion and conclusion.

\section{CURRENT STURUCTURE AND IMPORTANCE OF TURKISH CYPRIOT AGRICULTURE SECTOR}

The population of TRNC is around 286,964 in 2010. Agriculture is an important sector in the economy of the country. In 2010, the average annual share of agricultural sector in the total GDP was $7,8 \%$ and share of the agricultural products in the total export was $38,21 \%$. Added to this, share of the export of processed agricultural products and nutriments is $40.8 \%$ and this shows that the agriculture is the key actor. Furthermore, the ratio of agriculture in employment according to household labor force survey is $5.7 \%$ (SPO,2012).

Out of the total area of the country, $56,71 \%$ is agricultural land. Intensive irrigated crop productions include Citrus, Potatoes, Deciduous Fruits, Table Grapes, Vegetables and the other areas are used for the traditional Non Irrigated Crops production which includes Cereals, Animal Fodders, Olives, Carobs, Almond and Wine Grapes. Agricultural products for export mostly derive from the intensively irrigated crops.Animal Husbandry is spread all over the country and the share of the livestock production to gross agricultural product is about $46,49 \%$. Cattle, Sheep, Goats and the Poultry are the main animals, supplying animal products to the local market. Fisheries contribute a very small proportion to the GNP $(\% 0,4)$.There is however the odd importance in providing, for the rapidly increasing demand. Furthermore, the share of Forest resources in the GNP is 0,1\% (TRNC The Ministry of Agriculture and Natural Resources 2011, p. 6).

There is 1,398,123 donum (1donum = 0.92 decareor 919.03 square meter) of agricultural land, in TRNC, which is equal to $56,71 \%$ of the total. $19.94 \%$ of agricultural land is within Iskele Province located as a part of Karpaz Area (TRNC The Ministry of Agriculture and Natural Resourses 2011, pp. 19-20).

Iskele Province possesses $44.66 \%$ of the wheat cultivation area and produces $41.22 \%$ of the total production.In barley cultivation areas, this share is $17,32 \%$ and the production is $12,68 \%$. Iskele plays a significant role in potato cultivation; $26,47 \%$ of total potato growth area and $37,15 \%$ of total production is in Iskele. (TRNC The Ministry of Agriculture and Natural Resourses 2011, pp. 34-40).

In means of animal husbandry, Iskele's share in cattle, sheep and goat in order is $10,45 \%$, $38,86 \%$ and 13,21\%. (TRNC The Ministry of Agriculture and Natural Resources 2011, p. 84). 


\section{METHODOLOGY}

As indicated above, the research in this study aims determining the general and financial problems of agricultural sector in TRNC.Karpaz Area and Iskele, where agriculture is the main source of living, are chosen as the research region. Within this scope, agriculturists operating in this area are targeted and a researchwith convenience sampling and survey methods were applied during June and December 2011; 300 valid surveys were obtained.

Scale used in this research is formed with the help of academic studies focusing on small family businesses and adapted to TRNC agricultural enterprises. (Ay and Talaşlı, 2007; Kocabıyık and Altunay, 2008;Met, 2011; Emir, 2011; Ülker, 2006; Erdoğan, 2010; Basar, 2008; Bekçi and Usul, 2001; Torlak and Uçkun, 2005; Oktay and Güney, 2002; Kutlu and Demirci, 2007; Ersöz, 2010; Erol, 2010) Within this scope, survey, directed to respondents, consists of 4 sections. These are, in order; 10 questions about business and the sector; 10 questions about problems enterprises are facing; 9 questions about financial problems encountered and as the last section, 1 question about general performance of the enterprise. In the first section questions are multiple-choice whereas Likert scale is used in the other three sections.

Frequency and percentage analysis is used to emphasize information about business and sector and arithmetic mean is taken as a basis for interpreting financial problems. For instance, as a Likert scale, general average of the values between 1 (not usually a problem) and 5 (usually a problem) is calculated. Accordingly, variable with the highest average is considered as the most significant problem. Added to that, Likert scale is formed as between 1 (generally bad) and 5 (generally good) to evaluate the general performance of the business organization and arithmetic mean is calculated in this context. "One Sample t test" was applied to determine if the arithmetic mean average results statistically differ from coefficient 3 which points lack of decision.

Cronbach Alpha coefficient is taken as a basis in order to specify the reliability of scale used in this study.

\section{FINDINGS AND DISCUSSIONS}

Key findings acquired in the research will be discussed under the following topics: Information on Agriculturists and Sector, General Problems of Agricultural Sector, Financial Problems of Agricultural Sector and General Performance of Agricultural Enterprises.

\section{Information on Agriculturists and the Sector}

Data, acquired in the research, related to the agriculturists and agricultural sector is summarized below:

- $71 \%$ of 300 agriculturists are men.

- $49 \%$ of agriculturists are 41 years and older.

- $35 \%$ of agriculturists are high school graduate and $9 \%$ are university graduates.

- $77 \%$ of agriculturists are married. 
- Business experience of $59 \%$ of agriculturists is 16 years and more.

- Monthly revenue of $60 \%$ of agriculturists is 2500 TL or less.

- $25 \%$ of agriculturists engage in animal husbandry, $23 \%$ in plant agriculture and $45 \%$ in two or more agricultural areas.

- Most productive agricultural area is animal husbandry with $60 \%$ share and most productive species among animal husbandry is sheep farming with $58 \%$.

Table 1: Information on Agriculturists and the Sector

\begin{tabular}{|c|c|c|c|c|c|}
\hline \multirow[b]{2}{*}{$\begin{array}{l}\text { GENDER } \\
\text { (\%) }\end{array}$} & \multicolumn{5}{|c|}{ GROUPS AND (PERCENTAGES) } \\
\hline & $\begin{array}{l}\text { Male } \\
\text { (71) }\end{array}$ & \begin{tabular}{|l} 
Female \\
(21
\end{tabular} & & & \\
\hline $\begin{array}{l}A G E \\
(\%)\end{array}$ & $\begin{array}{l}20 \text { and below } \\
\text { (4) }\end{array}$ & $\begin{array}{l}21-30 \\
(18)\end{array}$ & \begin{tabular}{|l|}
$31-40$ \\
$(29)$
\end{tabular} & $\begin{array}{l}41-50 \\
(28)\end{array}$ & $\begin{array}{l}51 \\
\text { above } \\
\text { (21) }\end{array}$ \\
\hline $\begin{array}{l}\text { EDUCATION } \\
\text { (\%) }\end{array}$ & $\begin{array}{l}\text { Primary School } \\
\text { (33) }\end{array}$ & \begin{tabular}{|l} 
Secondary \\
School \\
(23)
\end{tabular} & $\begin{array}{l}\text { High School } \\
\text { (35) }\end{array}$ & $\begin{array}{l}\text { University } \\
\text { (8) }\end{array}$ & $\begin{array}{l}\text { Post- } \\
\text { Graduate } \\
\text { (1) }\end{array}$ \\
\hline $\begin{array}{l}\text { MARITAL } \\
\text { STATUS } \\
\text { (\%) }\end{array}$ & $\begin{array}{l}\text { Married } \\
\text { (77) }\end{array}$ & $\begin{array}{l}\text { Single } \\
(23)\end{array}$ & & & \\
\hline $\begin{array}{l}\text { BUSINESS } \\
\text { EXPERIENCE(yrs.) } \\
\text { (\%) }\end{array}$ & $\begin{array}{l}1-5 \\
(13)\end{array}$ & $\begin{array}{l}6-10 \\
(16)\end{array}$ & $\begin{array}{l}11-15 \\
(12)\end{array}$ & $\begin{array}{l}16-20 \\
(19)\end{array}$ & $\begin{array}{l}21-30 \\
(40)\end{array}$ \\
\hline $\begin{array}{l}\text { MONTHLY } \\
\text { REVENUE(TL) } \\
\text { (\%) }\end{array}$ & $\begin{array}{l}1350-1500 \\
(30)\end{array}$ & $\begin{array}{l}1501-2500 \\
(30)\end{array}$ & $\begin{array}{l}2501-3500 \\
(31)\end{array}$ & $\begin{array}{l}3501-4000 \\
(8)\end{array}$ & $\begin{array}{l}4001 \text { and } \\
\text { above } \\
\text { (1) }\end{array}$ \\
\hline $\begin{array}{l}\text { AGRICULTURAL } \\
\text { AREA } \\
\text { (\%) }\end{array}$ & $\begin{array}{l}\text { Animal } \\
\text { Husbandry } \\
\text { (25) }\end{array}$ & $\begin{array}{l}\text { Plants } \\
\text { (23) }\end{array}$ & $\begin{array}{l}\text { Forestry } \\
\text { (1) }\end{array}$ & $\begin{array}{l}\text { Fishery } \\
\text { (6) }\end{array}$ & $\begin{array}{l}\text { Two or more } \\
\text { agricultural } \\
\text { areas } \\
\text { (45) }\end{array}$ \\
\hline $\begin{array}{l}\text { MOST } \\
\text { PRODUCTIVE } \\
\text { AGRICULTURAL } \\
\text { AREA } \\
\text { (\%) }\end{array}$ & $\begin{array}{l}\text { Animal } \\
\text { Husbandry } \\
(60)\end{array}$ & \begin{tabular}{|l} 
Vegetable \\
growing \\
$(24)$
\end{tabular} & $\begin{array}{l}\text { Fishery } \\
(9)\end{array}$ & \begin{tabular}{|l}
$\begin{array}{l}\text { Fruit } \\
\text { growing }\end{array}$ \\
$(5)$
\end{tabular} & $\begin{array}{l}\text { Crops } \\
\text { (2) }\end{array}$ \\
\hline $\begin{array}{l}\text { MOST } \\
\text { PRODUCTIVE } \\
\text { ANIMAL } \\
\text { HUSBANDRY } \\
\text { (\%) }\end{array}$ & $\begin{array}{l}\text { Sheep raising } \\
\text { (58) }\end{array}$ & \begin{tabular}{|l|}
$\begin{array}{l}\text { Cattle } \\
\text { raising }\end{array}$ \\
$(21)$ \\
\end{tabular} & $\begin{array}{l}\text { Goat raising } \\
\text { (9) }\end{array}$ & $\begin{array}{l}\text { Fishery } \\
\text { (9) }\end{array}$ & $\begin{array}{l}\text { Beekeeping } \\
\text { (3) }\end{array}$ \\
\hline
\end{tabular}




\section{General Problems of Agricultural Sector}

As seen in Table 2, the most important problems of agricultural enterprises, in order, are: 'Position of Karpaz in regard to land use, in Cyprus Conflict' $(3,75)$, 'Natural disasters' $(3,7)$, 'Bureaucratic obstacles' (3,69), 'Negative effects of Cyprus Issue' $(3,68)$, 'Marketing of products,' $(3,6633)$, 'Competing with South Cyprus and foreign products' $(3,66)$ and 'Finance' $(3,64)$.

Table 2: Significant Problems of Karpaz Region Agricultural Enterprises, in Order of Importance

\begin{tabular}{|l|l|l|}
\hline $\begin{array}{l}\text { Order } \\
\text { No }\end{array}$ & Problems & $\begin{array}{l}\text { Arithmetic } \\
\text { Mean* }\end{array}$ \\
\hline $\mathbf{1}$ & Position of Karpaz in regard to land use, in Cyprus Conflict & 3,75 \\
\hline $\mathbf{2}$ & Natural Disasters & 3,70 \\
\hline $\mathbf{3}$ & Bureaucratic & 3,69 \\
\hline $\mathbf{4}$ & Effects of Cyprus Issue & 3,68 \\
\hline $\mathbf{5}$ & Marketing of Products & 3,66 \\
\hline $\mathbf{6}$ & Competing with South Cyprus and foreign products & 3,66 \\
\hline $\mathbf{7}$ & Finance & 3,64 \\
\hline $\mathbf{8}$ & Tax Applications & 3,56 \\
\hline $\mathbf{9}$ & Macroeconomic problems & 3,45 \\
\hline $\mathbf{1 0}$ & Human Resources & 3,44 \\
\hline $\mathbf{1}$
\end{tabular}

(*)Scale Intervals: 1=generally not a problem, 2=Not a problem, 3=Indecisive, 4= Problem, $5=$ generally a problem

\section{Financial Problems of Agricultural Enterprises}

Finance is stated as a problem of agricultural enterprises in Karpaz region, although it is not at the top of significant problems. As seen in Table 3, the most important finance problem of agricultural enterprises is pointed as 'High finance charges' (3.94). This is followed, in order, by 'Difficulties encountered in collections from market and official bodies' $(3,92)$, 'Limited incentive opportunity' $(3,85)$, 'Deposit obligation for credits' $(3,84)$, 'Costly investment credits' $(3,76)$, 'Insufficient business capital and problems encountered procuring the business capital' $(3,72)$ and 'Insufficient equity and difficulties faced obtaining investment credit.' $(3,70)$. 
Table 3: Significant Financial Problems of Karpaz Region Agricultural Enterprises, in Order of Importance

\begin{tabular}{|l|l|l|}
\hline Order & Problems & $\begin{array}{l}\text { Arithmetic } \\
\text { Mean* }\end{array}$ \\
\hline $\mathbf{1}$ & High finance charges & 3,94 \\
\hline $\mathbf{2}$ & $\begin{array}{l}\text { Difficulties encountered in collections from market and official } \\
\text { bodies }\end{array}$ & 3,92 \\
\hline $\mathbf{3}$ & Limited incentive opportunity & 3,85 \\
\hline $\mathbf{4}$ & Deposit obligation for credits & 3,84 \\
\hline $\mathbf{5}$ & Costly investment credits & 3,76 \\
\hline $\mathbf{6}$ & $\begin{array}{l}\text { Insufficient business capital and problems encountered procuring } \\
\text { the business capital }\end{array}$ & 3,72 \\
\hline $\mathbf{7}$ & $\begin{array}{l}\text { Insufficient equity and difficulties faced obtaining investment } \\
\text { credit. }\end{array}$ & 3,70 \\
\hline $\mathbf{8}$ & Changes in domestic economic market and foreign markets. & 3,54 \\
\hline $\mathbf{9}$ & $\begin{array}{l}\text { General economic situation and development level of capital } \\
\text { market }\end{array}$ & 3,21 \\
\hline
\end{tabular}

(*)Scale Intervals: 1=generally not a problem, 2=Not a problem, 3=Indecisive, 4= Problem, 5=generally a problem.

Cronbach Alpha coefficients, calculated for the reliability analysis of scales used for 'General Problems' and 'Financial Problems' surveys, are 0.754 and 0.758 in order. It is known that values greater than 0.7 are sufficient in regard to the reliability.(George and Mallery 2001, p. 217).

\section{General Performance of Agricultural Business Organizations}

In order to determine the general performance of Karpaz region agricultural enterprises, two methods, namely 'One sample t-test' and 'frequency analysis', are used. According to the Likert scale, which was formed by the values between 1 (generally bad) and 5 (generally good), average value indicating the performance is calculated as 2,59 . This shows the fact that general performance of agricultural enterprises is between indecisive and bad.

General performance of agricultural enterprises concentrates on indecisive option with 39\%, as seen in the Chart 1 . Moreover, the sum of bad and very bad options is $45 \%$ whereas the percentage of good and very good options is only $16 \%$. 


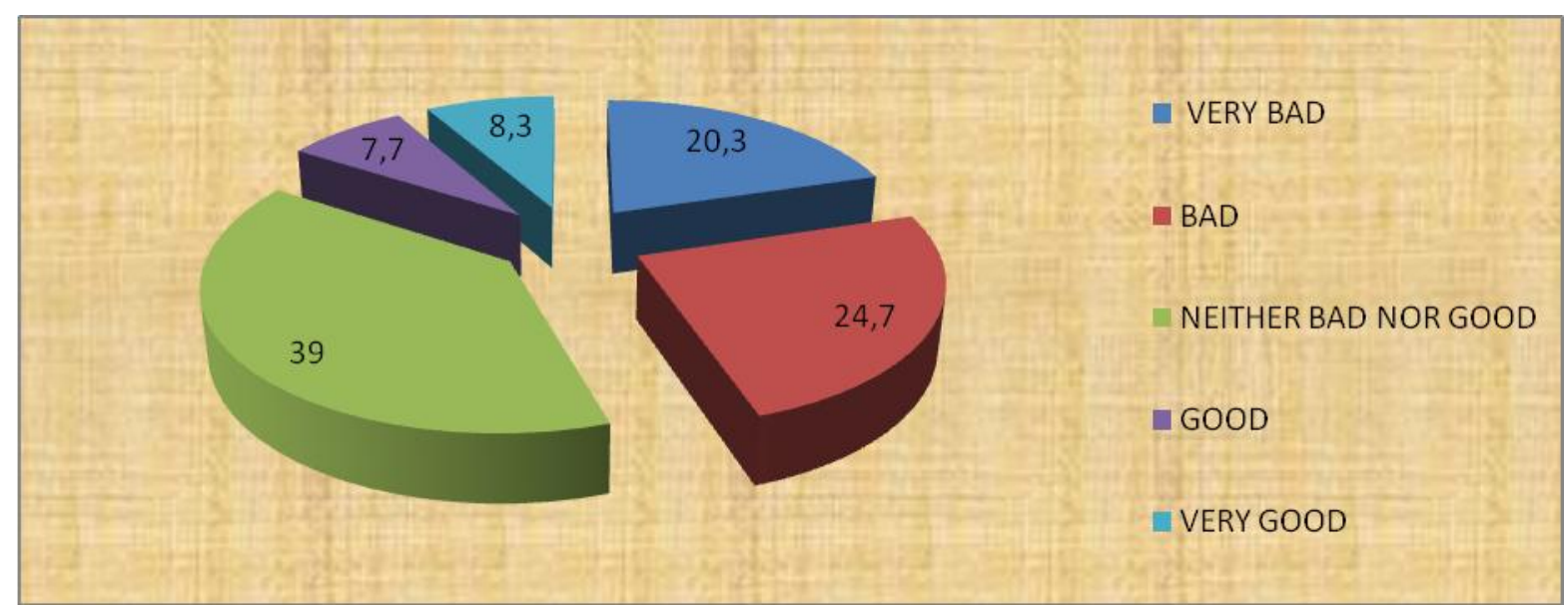

Chart 1: General Performance of Karpaz Region Agricultural Enterprises(\%)

ANOVA (one way) test was applied in order to determine if there is a positive statistical relationship between general performance of the agricultural enterprises and characteristics of enterprises. Within this framework, Tukey test was applied multiple comparisons purposely and positive relationship between agricultural enterprises' performance and characteristics of enterprises are aimed between 95\% confidence interval. Accordingly, statistical relationship are stated in Table 4 and summarized below:

- Increase in monthly revenue of agriculturist is perceived as an increase in success. However, statistically, positive variance stated monthly revenues are '1350-1500 TL' and '2501-3500 TL' intervals.

- Negative perception of performance is expressed for all sorts of agricultural engagement. Only business performance of 'fishing' and 'agricultural engagements over two cultures' proved to differ statistically.

Table 4: The Relationship Between the Characteristics of Agricultural Enterprises and Their Performance Using

\section{Analysis of Variance}

\begin{tabular}{|l|l|}
\hline Characteristics of the Enterprise & Enterprise Performance \\
\hline Monthly Revenue (Turkish Lira) & \\
\hline Between 1350 and 1500 & 2,2921 \\
\hline Between 1501 and 2500 & 2,4667 \\
\hline Between 2501 and 3500 & 2,8617 \\
\hline Between 3501-4000 & 3,0000 \\
\hline 4001 and above & 3,2500 \\
\hline (F) & $4,363^{*}$ \\
\hline Agricultural Area & \\
\hline Animal Husbandry & 2,6667 \\
\hline Plants & 2,5072 \\
\hline
\end{tabular}




\begin{tabular}{|l|l|}
\hline Forestry & 1,7500 \\
\hline Fishery & 1,8824 \\
\hline Two or more culture & 2,7037 \\
\hline (F) & $2,741^{*}$ \\
\hline$* p<0.05$ & \\
Note: Means are represented in terms of average attitudes of respondents \\
\hline
\end{tabular}

\section{CONCLUSION}

TRNC agriculture is an important sector in economy regarding the export potential. Iskele, which is chosen as the research area, hosts $40 \%$ of wheat and potato production and sheep farming although it covers only $20 \%$ of agricultural lands. The Iskele Province in Karpaz Peninsula is selected as area to be studied since this area is part of suggested lands to be handed over to South Cyprus Administration, alongside with part of Güzelyurt District as a key in settling the Cyprus Conflict.

Agriculturists' characteristics have both positive and negative aspects. $80 \%$ of agriculturists are aged below 50 years and more than $70 \%$ have more than 10 years of business experience, which are positive aspects. However, secondary school or lower education level being 56\%, should be taken into consideration generating the vision for professional and efficient agriculture.

The findings that the performances of agricultural enterprises are not perceived as positive coincide with the family income levels in the area. For instance, monthly revenue of $91 \%$ of agriculturists is $3500 \mathrm{TL}$ or less. Share of each member is $875 \mathrm{TL} / \mathrm{month}$ or $10,500 \mathrm{TL} /$ year, in other words $\$ 5800$, in afamily with 4 members. From the point of agriculturists, this is only $39 \%$ of per capita income, reported in 2011, which is \$15.108.(TC Ministry of Foreign Affairs, 2012, p.9)

The essential finding is that agriculturists are mainly engaged with animal husbandry and most productive species is sheep farming. This has to be taken into consideration deciding which area to be focused on in means of agricultural development.

Cyprus problem has negative reflections on Karpaz region agricultural enterprises; in case of solution, Karpaz region is planned to be given under the control of South Cyprus government. As a matter of fact, the most significant problem of agriculturists is indicated as 'Position of Karpaz in regard to land use, in Cyprus Conflict'. This is followed, in order, by 'Natural disasters', 'Bureaucratic obstacles', 'Negative effects of Cyprus Issue', 'Marketing of products,', 'Competing with South Cyprus and imported foreign products' and ,'Finance'.

In spite of the fact that finance is not on the top of significant problems of agriculturists, the financial problems that need to be taken into account in scope of incentive policiesare as follows in order: 'High finance charges', 'Difficulties encountered in collections from market and official bodies', 'Limited incentive opportunity', 'Deposit obligation for credits', 'Costly investment credits', 'Insufficient business capital and problems encountered procuring the business capital' and 'Insufficient equity and difficulties faced obtaining investment credit.' 


\section{REFERENCES}

Ay, Hakkı Mümin ve E. Talaşlı (2007), “Türkiye'de Kobi'lerin İhracattaki Yeri ve Karşılaştıkları Sorunlar", Selçuk Üniversitesi Karaman i. I. B. F . Dergisi Yerel Ekonomiler Özel Sayısı, Mayıs 2007

Basar, M. (2008), "Finansal Sorunlar Çıkmazında KOBíler ve Basel II Süreci”,I. UluslararasıSempozyum: KOBI'ler ve Basel II”, BildirilerKitabı, 02-03-04 Mayıs 2008, İzmir Ekonomi Üniversitesi İzmir/ Türkiye

Bekçi, İ ve Usul, H. (2001), "GöllerBölgesindekiKüçük ve Orta Boy İşletmelerinFinansalSorunları ve ÇözümÖnerileri", SüleymanDemirel Üniversitesi iktisadi ve IdariBilimlerFakültesi Dergisi, 6(1): 111-125.

Emir, M. (2011), “FinansKaynakları ve Samsun'dakiKOBi’lerinDurumu”, Samsun Sempozyumu 2011

Erdoğan, HilalHümeyra (2010), “Global Mali Krizin Kobi’lerin FinansalYapılarıÜzerineEtkileri: İzmir Illi TekstilSektöründeBirAraştırma”, YüksekLisansTezi, T.C.SüleymanDemirelÜniversitesiSosyalBilimlerEnstitüsü, İşletmeAnabilim Dalı, Isparta - 2010

Erol, M. (2010), “EkonomikKriz ve KOBi’ler”, Girişimcilik ve Kalkınma Dergisi (5:1) 2010.

Ersöz, V. (2010), AB, Türkiye ve Konya'daKOBi'lerinYapısı, Sorunları ve ÇözümÖnerileri, Konya TicaretOdası, Şubat-2010.

George, D. - Mallery, P. (2001), SPSS For Windows, Third Edition, Allyn\& Bacon/Pearson Education Company, USA.

Kocabıyık, T. Ve M.A. Altunay (2008), “ArtanRekabetOrtamındaKOBi'lerinSorunları ve Buna ilişkinBirAraştırma", Marmara Üniversitesi i.i.B.F Dergisi, 25(2).

Kutlu, H.A. ve Demirci, N.S. (2007), "KOBi'lerinFinansalSorunları ve ÇözümÖnerileri”, 4. KOBi'ler ve VerimlilikKongresi, İstanbul Kültür Üniversitesi, 7-8 Aralık 2007

Met, Ö. (2011), "Küçük ve OrtaÖlçekliişletmelerinFinansalSorunları: KırgızistandaBirAraştırma", Sosyoekonomi, 2011-1.

Oktay, E. ve Güney, A., (2002), "Türkiye'de KOBi'lerinFinansmanSorunu ve Çözüm Önerileri","21.Yüzyılda Kobi'ler: Sorunlar, Fırsatlar ve ÇözümÖnerileri” Sempozyumu, 03-04 Ocak 2002, DoğuAkdeniz Üniversitesi, K.K.T.C.

SPO (2012), Economic and Social Indicators 2010, TRNC State Planning Organization Follow and Coordination Department, July 2012; http://www.devplan.org/Frame-eng.html 
TC DışişleriBakanlığı (2012), KKTC'yeYapılan TC yardımları 2011 YılıFaaliyetRaporu, T.CLefkoşaBüyükelçisiYardımHeyetiBaşkanlığı.

Torlak, Ö. ve Uçkun, N. (2005), “Eskisehir'dekiKOBi'lerinPazarlama ve FinansmanSorunlarıAraKesiti", SosyalBilimler Dergisi 2005/1.

TRNC The Ministry of Agriculture and Natural Resourses (2011), Agricultural Structure and Production 2010, Statistic and Planning Division, Nicosia-2011.

Ülker, F. (2006), “AvrupaBirliği'nde ve Türkiye'de Küçük ve Orta Boy İşletmeler”, YüksekLisansProjesi, T.C.KahramanmaraşSütçü İmam ÜniversitesiSosyalBilimlerEnstitüsülktisatAnabilim Dalı, KahramanmaraşEylül-2006. 